\title{
On the Price of German Treasury Bills
}

WP n. ${ }^{\circ} 2012 / 14$

DOCUMENTO DE TRABALHO WORKING PAPER 


\title{
On the Price of German Treasury Bills
}

\author{
Emanuel Leão * \\ Sérgio Lagoa
}

WP n.० 2012/14

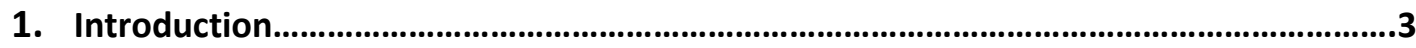

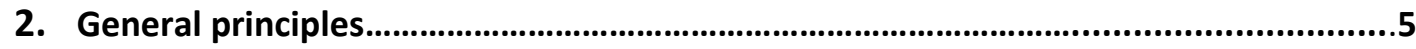

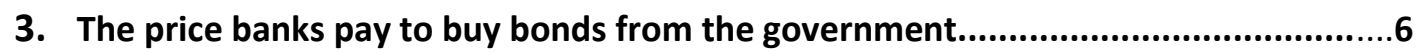

3.1 Step. 2. Compute the expected annual rate of return banks require.....................7

3.2 Step 3. Combine steps 1 and 2 to obtain the price banks are willing to pay.........14

4. The price households and nonbank ..rms pay for buying T-Bills from

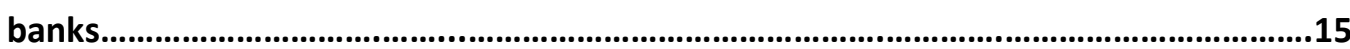

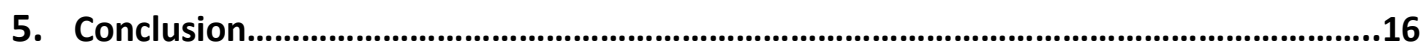

References................................................................................................................................17

*Departament of Political Economy, ISCTE - University Institute of Lisbon and DINÂMIA'CET-IUL (sergio.lagoa@iscte.pt). * *Departament of Political Economy, ISCTE - University Institute of Lisbon and DINÂMIA'CET-IUL (emanuel.leao@iscte.pt). 


\section{On the Price of German Treasury Bills}

Emanuel R. Leao

Departament of Political Economy, ISCTE- Lisbon University Institute and DINAMIA-CET, Avenida das Forcas Armadas, 1649-026 Lisboa, Portugal Phone 00351217903490

Fax 00351217964710

E-mail: emanuel.leao@iscte.pt

Sergio C. Lagoa

Departament of Political Economy, ISCTE- Lisbon University Institute and DINAMIA-CET, Avenida das Forcas Armadas, 1649-026 Lisboa, Portugal Phone 00351217903436

Fax 00351217964710

E-mail: sergio.lagoa@iscte.pt 


\section{On the Price of German Treasury Bills}

\section{$\underline{\text { Abstract }}$}

In this paper, we examine the primary and secondary markets for German treasury bills. We look in great detail at the rationale behind banks' decisions concerning the yield they require to be willing to buy treasury bills in the primary market; and we also mention the reasoning behind household and nonbank firm decisions concerning the price they are willing to pay to buy these bills in the secondary market. We use data from real world tenders to show that the bids set by banks conform to what our theoretical framework would predict. In particular, we show that current monetary policy and the markets' expectations regarding its future path can be used to define a range where the banks bids lie.

Keywords: treasury bills, interest rates, monetary policy, interbank loans market

JEL Classification: E43, E52, G12, H63. 


\section{Introduction}

Treasury-Bills (T-Bills) rates play a key role in financial markets as they are commonly used as the return of the risk-free asset. Consequently, in the study of monetary policy transmission, it is relevant to understand the impact of policy interest rates on T-bills interest rates. As a result, the issuing of government bonds in the primary market has been widely studied. Several authors have studied the relation between the federal funds (FF) rate and T-bills rate. These two variables are linked by the expectations hypothesis, with the T-bills rate being equal to the expected FF rate up to the maturity of the T-bills plus a risk premium (Sarno and Thornton, 2002). Cook and Hahn (1988) was one of the first studies finding a strong effect of the FF rate on T-bills interest rates on the period 1974-79. Using a larger sample for the period 1974-99, Sarno and Thornton (2002) found a long-run relation between those two rates, which remains stable across different monetary policy regimes. Interestingly, the adjustment towards the long-run equilibrium is done mostly by the FF rate, and were found important asymmetries in interest rates dynamics. Elder (2001) founds that positive shocks on the FF rate increase T-bills rates but leads to an increase of the volatility of T-Bills holding period excess returns. However, that author does not find a relation between the volatility of the FF rate and the risk premia of T-bills returns. On the contrary, Jordà and Salyer (2003) show that the predictions of a limited participation model are confirmed as higher uncertainty in the FF rate implies lower yields for three- and six-months T-bills. In the same line of research, Nyborg, Rydqvist and Sundaresan (2002) examine how bidders' behaviour is affected by increased uncertainty at the time of bidding in the Swedish treasury auctions.

A related issue is the risk premia in the interbank market, i.e., the difference between the interbank rate and the T-bill rate with the same maturity. Wingerber (2011) shows that unexpected changes in the FF rate have a significant effect on interbank risk premia, with the impact being different for changes taking place at scheduled and unscheduled FOMC meetings.

Even though there is wide evidence of the effect of the FF rate on Tbills rates, the expectation hypothesis applied to T-Bills has received little empirical support. Guidolin and Thornton (2008) argue that the failure of the expectation hypothesis is caused by the inability of investors to correctly predict short-term rates (1- and 3-month T-Bill yields).

Apart from the relationship between policy rates and T-Bills, the literature has studied the effect of other factors on T-bills returns. Carson (1959), Brimmer (1962), Bolten (1973), Boatler (1975) and Smith 
(1996), among others, discuss the treasury bill auction procedures in the US with the goal of determining which procedure would maximize government revenues. Garbade and Ingber (2005) show how recent advances in communications and information-processing technologies have affected the precise way in which auctions are carried out. Fleming (2002) looks at the relationship between the size of treasury bond issues in the US and their liquidity. Amihud and Mendelson (1991) empirically show that, as expected, yields are smaller for bills with lower liquidity. Anderson (1997) use error correction models to study how transaction costs affect yield movements in the primary US treasury bill market. Duffee (1996) studies segmentation in the US treasury bill market. Cammack (1991) compares T-Bills auction prices with contemporaneous secondary market prices in the US to assess how much imperfect information is present in the market. Balduzzi, Elton and Green (2001) examine the response of the price of government bonds to scheduled releases of macroeconomic news in the US.

In this paper, we focus on the issuing of T-Bills by the German government, making two contributions to the literature. Firstly, this paper explores the relation between the T-Bills rate and the interbank rate, indicating an interval for the T-Bills rate in the primary market attending to the expected evolution of the monetary policy. Secondly, we present some chosen examples in support of the prepositions formulated.

In normal times when banks go to a tender where the government is to issue short-term bonds, the yield they require is similar to the return they could obtain by lending to other banks in the interbank market for the same maturity. This is because in normal times (i.e., outside crisis periods), banks regard both investments as relatively safe. We also know that, because loans to other banks are not liquid whereas short-term government bonds are very liquid, the yield required to buy Treasury bonds is smaller than the interbank loans with the same maturity. In this paper, we try to be more precise about the exact yield banks require to buy short-term German government bonds in the primary market. We do it by taking into account the whole spectrum of maturities available in the interbank loans market, and indicating an interval where the T-bill yield should be.

The empirical test of the above prepositions is relevant because the relation between T-bills and interbank rates rests on the assumption that those markets are not segmented. If it exists an important set of investors for whom T-bills and interbank loans are not close substitutes, there is no reason for the no-arbitrage condition between the two markets to hold.

Therefore, using dates where treasury bill auctions actually took 
place, we compare the interest rate that our framework would predict with the interest rate that banks actually set in their bids. To do that, we use data on six month German treasury bills auctions supplied by the Bundesbank and data on interbank loan rates. In all cases, the average yield set by banks in the auctions conforms to what our theory would predict.

The structure of the article is as follows. Section 2 reviews some basic notions concerning the valuation of financial assets. In Section 3, we look at the rationale behind banks' decisions concerning the yield they require to be willing to buy German government bills in the primary market. Section 4 examines households and nonbank firms' decisions regarding the price they are willing to pay to buy treasury bills in the secondary market. Section 5 concludes.

\section{General principles}

As mentioned above, our main goal is to devise a framework to explain the yield banks require to be willing to buy government bonds in the primary market. More generally, the paper looks at the determination of the price of Treasury Bills in both the primary and secondary markets. We look at: (I) how do banks decide the price they are willing to pay to buy T-Bills in the primary market (the auctions where the German government originally issues the T-Bills); and (II) what price are households willing to pay for T-Bills in the secondary market, i. e., when they go to a bank to purchase these bills.

In both cases, the difficult task is to obtain the average (expected) rate of return the buyers require in order to be willing to buy the bonds. Before going down to the specifics of each case - (I) and (II) - let us recall that, in general, in order to decide the average rate of return they require to buy a certain security, banks and other investors combine two ideas:

(i) After comparing the liquidity and risk characteristics of two securities ( $\mathrm{A}$ and $\mathrm{B}$ ), if they prefer security $\mathrm{A}$, then they will only be willing to buy security $B$ if the expected rate of return of $B$ is higher. In other words, if:

Expected rate of return of $\mathrm{B}=$ Expected rate of return of $\mathrm{A}+\mathrm{RLP}$

, where RLP denotes a risk and liquidity premium.

(ii) In particular, they compare the liquidity and risk characteristics

of each security to those of securities with high liquidity and low risk whose rate of return they already know. 
Each security has certain characteristics concerning liquidity, market risk and default risk. By liquidity, we mean the average time and transaction costs involved in selling the security. By market risk, we mean the risk that if we need to sell the security its price could be low. By default risk we mean the risk that the issuer of the security may not fulfill the planned payouts.

\section{The price banks pay to buy bonds from the gov- ernment}

Consider, as an example, the issuance of bonds by the German government. Specifically, let us look at bonds with face value $€ 10$, zero coupon rate and maturity within six months. The German government announces today the issuance of 50.000 bonds with these characteristics. A tender is organized where each bank makes a bid, i.e., it indicates the number of bonds it would like to buy and the price it would be willing to pay for each bond. Afterwards, the German government decides what bids it wants to accept (in particular, it may end up selling less than the announced 50.000 bonds).

We want to know what price will banks set in their bids (what price are they willing to pay for each bond with those characteristics). To obtain an answer, we take three steps:

Step 1. Make an estimate of the payouts the bonds entitle their owners to receive

Step 2. Compute the expected annual rate of return banks require in order to accept buying the bonds (taking into account their risk and liquidity characteristics)

Step 3. Combine steps 1 and 2 to obtain the price banks are willing to pay.

Let us then follow these three steps in order to obtain the price. In Step 1, the investor makes an estimate of the payouts the bonds entitle their owners to receive. Since these are zero-coupon bonds, they only entitle their owner at maturity to receive the face value (€10): 


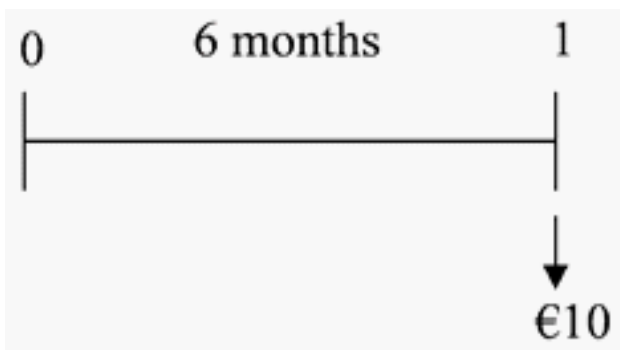

\subsection{Step 2. Compute the expected annual rate of return banks require}

In order to decide the average rate of return they require to buy the bonds, banks will compare their liquidity and risk characteristics with the liquidity and risk characteristics of alternative high liquidity/low risk investments whose rate of return they already know. These alternative investments are:

(a) A six month loan in the interbank market. In this case:

- the liquidity of the application is zero (only at maturity will the funds lent be recovered)

- market risk is zero (in a loan to another bank, the amount and interest rate involved are set at the beginning and so the amount paid out at the end is known from the start)

- default risk is low if the investment horizon is only a few months (if a bank is near bankruptcy, we can usually see that event coming months before)

(b) A succession of overnight loans in the interbank market during the next six months. In this case:

- liquidity is high because these are overnight loans;

- market risk is low, because the overnight interbank rate is linked to the central bank interest rate which normally changes smoothly over time;

- default risk is low because a normal bank does not go bankrupt from one day to the next.

(c) Making deposits in the overnight deposit facility of the central bank - which exists at least in the case of the ECB - during the next six months. In this case:

- liquidity is high because these are overnight deposits; 
- market risk is low, because the central bank normally changes its interest rates smoothly over time;

- default risk is low - almost zero - because the central bank can print money, if needed, to pay its debts (the only limit would be the fear of causing inflation through excessive money printing).

The rates of return of alternatives (a), (b) and (c) all stem from present and expected central bank interest rates.

We next state the risk and liquidity characteristics of the T-Bills under study:

- liquidity is high because one can normally sell T-Bills to a bank without much difficulty or cost;

- market risk is low because, if we want to sell before maturity, the amount a bank will pay us depends on the alternative this bank has to apply the same funds. This alternative is making an interbank loan with the same maturity. The interest rate on this interbank loan does not fluctuate a lot because it stems from the central bank repo rate which usually evolves in a stable manner. As a result, the amount one can expect to obtain from selling the T-Bill at any date before maturity is easy to predict with only small errors, i. e., market risk is low.

- default risk is low because the issuer is the German government.

Let us compare the risk and liquidity characteristics of the T-Bills with those of the alternatives (a), (b) and (c) ${ }^{1}$. In practice, alternative (c) is ignored because it has a much lower rate of return than (a) and (b) - and so it is not an alternative banks would really consider.

So, we proceed by first comparing the risk and liquidity characteristics of the T-Bills with those of alternative (a). In terms of risk of default, they are similar (very low). In terms of market risk, they are also similar (if held to maturity, the T-Bills have no market risk; and loans to another bank also have no market risk). Regarding liquidity, there is a big difference: T-Bills are very liquid whereas loans to other banks for six months are not liquid at all. This makes buying six month T-Bills - i.e., lending to the German government for six months - preferable to lending to other banks for six months. As a consequence, banks will require a rate of return for buying the six month T-Bills which is lower than the six month rate available in the interbank money market (IMM). Mathematically:

\footnotetext{
${ }^{1}$ The purpose of this comparison is to determine the rate of return on the T-Bills that banks will require (in order to be willing to buy them).
} 


$$
R_{6 M}^{T-\text { Bills }}<R_{6 M}^{I M M}
$$

The second comparison that matters is to look at the risk and liquidity features of the T-Bills and comparing them to those of alternative (b). In terms of default risk, they are very similar. In terms of liquidity, both are very liquid. The big difference occurs in market risk. If we hold the T-Bills to maturity, we will receive the face value whereas if we opt for a succession of loans in the overnight interbank market for six months, we have no guarantee regarding the amount we will receive (because the central bank may unexpectedly lower its key rates in the middle of the six months thereby making the interbank overnight rate drop). As a consequence, banks will demand a rate of return for buying the T-Bills which is lower than the amount they would receive by making successive loans in the overnight interbank market for six months. Mathematically:

$R_{6 M}^{T-\text { Bills }}<$ average of overnight interbank interest rates expected over the next 6 months

The problem with this equation is that the "average of the overnight interbank interest rates expected over the next six months" is an expectation and so cannot be directly observed. To overcome this weakness, we will try to obtain an equation that relates the rate of return banks want on the T-Bills with today's overnight interbank interest rate (a value which can be observed). To do this, we need to make assumptions about the expectations banks have regarding the evolution of monetary policy during the next six months:

\subsubsection{Scenario A. Banks expect the central bank to keep its reference rate unchanged for the next six months}

As we know, in normal times the interbank overnight interest rate tends to be very close to the main policy rate of the central bank.

If banks expect monetary policy to remain unchanged over the next six months, then today's overnight rate is equal to the average overnight rate expected for the next six months, i.e.:

$R_{o / n}^{I M M}=$ average of overnight interbank interest rates expected over the next 6 months 
Combining equation (3) with equation (2) we conclude that, under Scenario A:

$$
R_{6 M}^{T-\text { Bills }}<R_{o / n}^{I M M}
$$

\subsubsection{Scenario B. Banks expect the central bank to lower its reference rate during the next six months}

If banks expect the central bank to reduce its reference rates over the next six months, then today's overnight rate is higher than the average overnight rate expected for the next six months, i.e.:

$R_{o / n}^{I M M}>$ average of overnight interbank interest rates expected over the next 6 months

Combining equation (5) with equation (2) we conclude that, under Scenario B:

$$
R_{6 M}^{T-\text { Bills }}<R_{o / n}^{I M M}
$$

\subsubsection{Scenario C. Banks expect the central bank to increase its reference rate during the next six months}

If banks expect the central bank to increase its reference rates over the next six months, then today's overnight rate will be lower than the average overnight rate expected for the next six months, i.e.:

$R_{o / n}^{I M M}<$ average of overnight interbank interest rates expected over the next 6 months

By looking at equations (7) and (2) we cannot arrive at any conclusion regarding the relationship between $R_{6 M}^{T-B i l l s}$ and $R_{o / n}^{I M M}$. Note, however, that if we imagine a world without uncertainty the only advantage of the six month T-Bills over a succession of overnight loans evaporates (in a world with $100 \%$ certainty, we could compute with certainty the amount we would receive by investing successively in the overnight market for six months). So, in a world with $100 \%$ certainty, instead of equation (2) we would have: 
$R_{6 M}^{T-\text { Bills }}=$ average of overnight interbank interest rates expected over the next 6 months

Combining equation (7) with equation (8), we would arrive at the following relation between $R_{6 M}^{T-\text { Bills }}$ and $R_{o / n}^{I M M}$ :

$$
R_{6 M}^{T-\text { Bills }}>R_{o / n}^{I M M}
$$

So, under Scenario C, the only thing we can say is: if the uncertainty surrounding economic developments in the next six months is low, then equation (9) probably holds. The more uncertain is the environment facing us in the next six months, the more likely it is that this inequality "> will switch to " $<$ ".

\subsubsection{Real world examples}

Let us now look at some of the auctions that actually took place and see if the rate asked by the banks conforms to what our reasoning would predict. In what follows, the data on six-month "Bubills" - Treasury Bills of the Federal Republic of Germany - were kindly supplied by the Bundesbank. The interbank overnight and six- month interest rates were obtained from the site www. global-rates.com. To gauge the expectations regarding monetary policy we assume perfect foresight, i.e., we assume that what eventually happened was what markets had expected. For example, between October 6th 2000 and June 6th 2003 the ECB lowered interest rates several times. So, whenever in a period of six months the ECB actually decreased rates, we assume that in the beginning of that period markets were expecting a decrease in central bank rates.

Example 1: Markets expecting a decrease in central bank rates over the next six months As a first example, consider the auction made by the German government in July 2001. During July 2001, the average value of the six month Euribor rate (interbank six month rate) was $4,387 \%$.

Equation (1) then tells us that:

$$
\begin{gathered}
R_{6 M}^{T-\text { Bills }}<R_{6 M}^{I M M} \\
R_{6 M}^{T-\text { Bills }}<4,387 \%
\end{gathered}
$$


Between October 6th 2000 and June 6th 2003 the ECB lowered interest rates several times. Assuming perfect foresight, we may then say that in July 2001 we were under Scenario B (markets expecting a decrease in central bank rates ${ }^{2}$ ). Equation (6) then tells us that banks will set their bids so that:

$$
R_{6 M}^{T-\text { Bills }}<R_{o / n}^{I M M}
$$

Since in July 2001 the average Eonia (interbank overnight rate) was $4,505 \%$, we can write the previous equation $\mathrm{as}^{3}$ :

$$
\Leftrightarrow R_{6 M}^{T-\text { Bills }}<4,505 \%
$$

Combining (10) and (11), we would predict that interest rate banks would be willing to pay for the Bubills would be:

$$
R_{6 M}^{T-\text { Bills }}<4,387 \%
$$

In the July 2001 Bubills auction, the average yield was:

$$
R_{6 M}^{T-\text { Bills }}=4,3 \%
$$

In short, the average yield which actually occurred in the July 2001 Bubills auction conforms to what our reasoning would predict.

\section{Example 2: Markets expecting unchanged central bank rates}

over the next six months Let us now consider the auction made by the German government in October 2004. During October 2004, the average value of the six month Euribor rate (interbank six month rate) was $2,191 \%$.

Equation (1) then tells us that:

$$
R_{6 M}^{T-\text { Bills }}<R_{6 M}^{I M M}
$$

\footnotetext{
${ }^{2}$ The ECB actually decreased rates in August, September and November 2001.

${ }^{3}$ The fact that, at the time, the Euribor was lower than the overnight signals that markets were expecting a decrease.
} 


$$
R_{6 M}^{T-\text { Bills }}<2,191 \%
$$

From June 6th 2003 until December 6th 2005, the ECB kept its reference rates unchanged. Assuming perfect foresight, we may then say that in October 2004 we were under Scenario A (markets expecting no change in central bank rates). Equation (6) then tells us that banks will set their bids so that:

$$
R_{6 M}^{T-\text { Bills }}<R_{o / n}^{I M M}
$$

Since in October 2004 the average Eonia (interbank overnight rate) was $2,111 \%$, we can write the previous equation as:

$$
\Leftrightarrow R_{6 M}^{T-\text { Bills }}<2,111 \%
$$

Combining (12) and (13), we would predict that interest rate banks would be willing to pay for the Bubills would be:

$$
R_{6 M}^{T-\text { Bills }}<2,111 \%
$$

In the October 2004 Bubills auction, the average yield was:

$$
R_{6 M}^{T-\text { Bills }}=2,069 \%
$$

In short: the average yield which actually occurred in the October 2004 Bubills auction conforms to what our reasoning would predict.

Example 3: Markets expecting an increase in central bank rates

over the next six months As a final example, let us consider the auction made by the German government in January $2007^{4}$. During January 2007, the average value of the six month Euribor rate (interbank six month rate) was $3,890 \%$.

Equation (1) then tells us that:

$$
R_{6 M}^{T-B^{3 i l l s}}<R_{6 M}^{I M M}
$$

\footnotetext{
${ }^{4}$ The first worries in financial markets concerning the problems in "US subprime loans" appeared at the end of February 2007.
} 


$$
R_{6 M}^{T-\text { Bills }}<3,890 \%
$$

From December 6th 2005 until July 9th 2008, the ECB increased interest rates several times. Assuming perfect foresight, we may then say that in January 2007 we were under Scenario C (markets expecting increases in central bank rates ${ }^{5}$ ). Equation (9) then tells us that banks will set their bids so that:

$$
R_{6 M}^{T-\text { Bills }}>R_{o / n}^{I M M}
$$

Since in January 2007 the average Eonia (interbank overnight rate) was $3,563 \%$, we can write the previous equation as:

$$
\Leftrightarrow R_{6 M}^{T-\text { Bills }}>3,563 \%
$$

Combining (14) and (15), we would predict that interest rate banks would be willing to pay for the Bubills would be:

$$
3,563 \%<R_{6 M}^{T-\text { Bills }}<3,890 \%
$$

In the January 2007 Bubills auction, the average yield was:

$$
R_{6 M}^{T-\text { Bills }}=3,716 \%
$$

Once again, the average yield which actually occurred in the January 2007 Bubills auction conforms to what our reasoning would predict.

\subsection{Step 3 Combine steps 1 and 2 to obtain the price banks are willing to pay}

Combining the expected payout obtained in step $1(€ 10)$ with the average rate of return obtained in step 2, we arrive at the price banks are willing to pay. In Example 1, that price would be:

$$
\frac{10}{P^{T-B i l l s}}=(1+0.043)^{6 / 12} \Leftrightarrow
$$

\footnotetext{
${ }^{5}$ The ECB actually increased rates in March and June 2007.
} 


$$
\begin{gathered}
\Leftrightarrow P^{T-\text { Bills }}=\frac{10}{(1+0.043)^{6 / 12}} \Leftrightarrow \\
\Leftrightarrow P^{T-\text { Bills }}=9,79
\end{gathered}
$$

Using similar computations, we arrive at a price $€ 9,90$ for Example 2 and $€ 9,82$ for Example 3 .

Note that we have thus arrived at an answer to our starting question: "What price are banks willing to pay for the T-Bills?".

\section{The price households and nonbank firms pay for buying T-Bills from banks}

When households and nonbank firms go to a bank in order to buy TBills, the price they are ready to pay is the result of a reasoning similar to the one we have just made (steps 1, 2 and 3 above).

The only difference is that in step 2 the benchmarks - alternatives with high liquidity and low risk available to households and nonbank firms ${ }^{6}$ - are:

(i) Savings deposits in banks:

- in this case liquidity is high because banks usually raise no objections to the conversion of saving deposits into checkable deposits;

- there is some market risk because if we make this conversion before the dates scheduled for interest payments, we will lose part of the interest;

- default risk is usually small for financially sound banks.

(ii) Treasury Bills (we have already seen this above in this article):

- liquidity is high because they can easily be sold to a bank;

- market risk is low (the price of T-Bills does not fluctuate a lot)

- default risk is low because the issuer is the German government.

The determining aspect in this comparison is that if one decides to withdraw a savings deposit made with a bank before maturity, one will at least receive the amount initially deposited. In the case of TBills, although unlikely, it is possible that when one sells the bill before

\footnotetext{
${ }^{6}$ Households and nonbank firms don't have access to the interbank loans market.
} 
maturity one will receive less than the amount initially spent buying it. This makes households prefer the risk/liquidity combination of savings deposits to that of T-Bills. Hence:

$$
R_{6 M}^{S D}<R_{6 M}^{T-\text { Bills }}
$$

Remember that the interest rate on savings deposits $\left(R_{6 M}^{S D}\right)$ is closely linked to interbank money rates which means it is ultimately determined by current and expected central bank rates.

In order to test our prediction, we looked at the German data on deposits rates and T-Bills from January 2003 to November 2007 (See figure below). This period can be considered a period of "normality", since the effects of the Subprime financial crisis where still mild during 2007. 7 During this period we observe that the inequality (16) was verified, with the T-Bill rate almost always above the deposits rate.

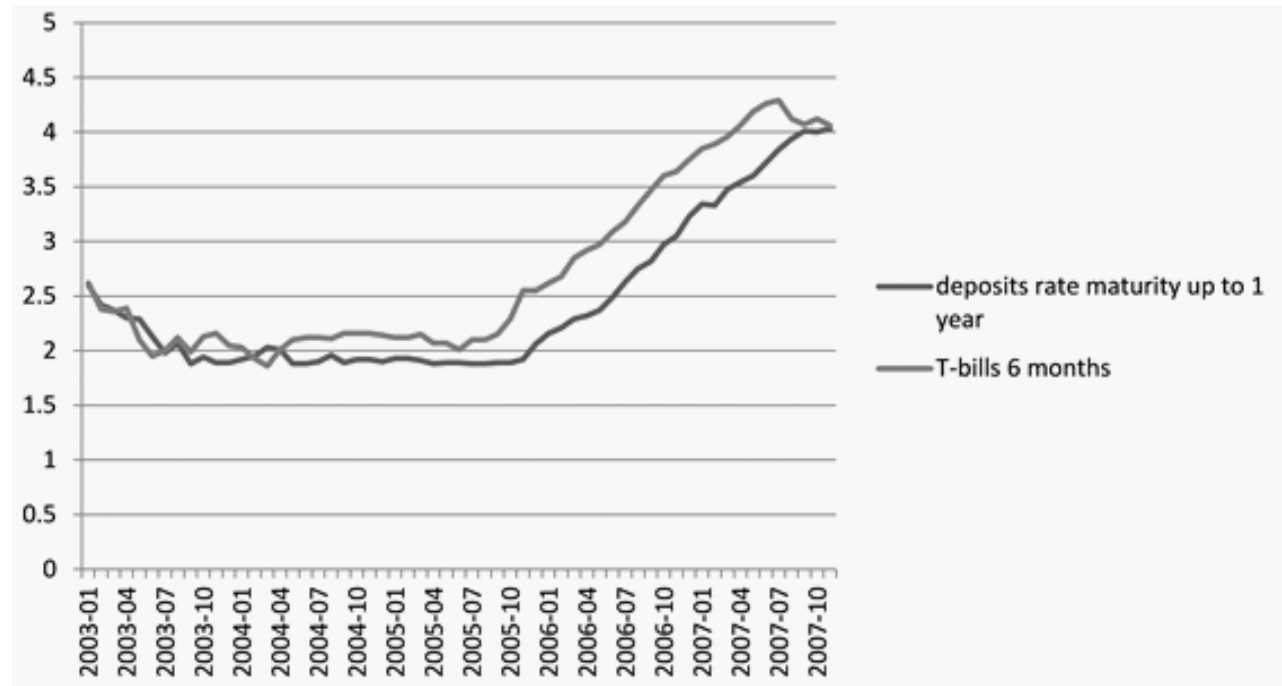

Deposits rate with maturity up to 1 year and 6-months T-bills yields on the secondary market.

Source: Bundesbank

\section{Conclusion}

This article focused on the determination of the price of Treasury Bills both in the primary market and in the secondary market. We have

\footnotetext{
${ }^{7}$ In December 2007 started the contraction in the US economy according with the NBER's Business Cycle Dating Committee.
} 
devised a framework to predict what interest rate banks should rationally set in their bids when they go to a government bond auction to buy treasury bills. Using data from the German government bond auctions, we were able to correctly predict the range where the bids were set.

As a suggestion for further research, we think it would be interesting to try to gauge expectations of future monetary policy trends using surveys of a panel of banks, instead of the perfect foresight strategy we adopted in this article.

\section{References}

[1] Amihud, Y. and Mendelson, H. (1991). "Liquidity, Maturity, and the Yields on U. S. Treasury Securities", The Journal of Finance 46: 1411-1425.

[2] Anderson, H. (1997). "Transaction Costs and Nonlinear Adjustment Towards Equilibrium in the US Treasury Bill Market", Oxford Bulletin of Economics and Statistics 59: 465-484.

[3] Balduzzi, P., Elton, E. and Green, T. (2001). "Economic News and Bond Prices: Evidence from the U.S. Treasury Market", Journal of Financial and Quantitative Analysis 36: 523-543.

[4] Boatler, R. W. (1975). "Treasury Bill Auction Procedures: Comment", The Journal of Finance 30: 895-899.

[5] Bolten, S. (1973). "Treasury Bill Auction Procedures: an Empirical Investigation", The Journal of Finance 28: 577-585.

[6] Brimmer, A. (1962). "Price Determination in the United States Treasury Bill Market", The Review of Economics and Statistics 44: 178-183.

[7] Cammack, E. (1991). "Evidence on Bidding Strategies and the Information in Treasury Bill Auctions", Journal of Political Economy 99: 100-130.

[8] Carson, D. (1959). "Treasury Open Market Operations", The Review of Economics and Statistics 41: 438-442.

[9] Cook, T. and Hahn, T. (1989). "The Effect of Changes in the Federal Funds Rate Target on Market Interest Rates in the 1970s", Journal of Monetary Economics, Vol. 24 (3), pp. 331-351.

[10] Duffee, G. R. (1996). "Idiosyncratic Variation of Treasury Bill Yields", The Journal of Finance 51: 527-55.

[11] Elder, J. (2001). "Can the Volatility of the Federal Funds Rate Explain Premium in Treasury Bill Returns?", Journal of Macroeconomics, Vol. 23, No.1 pp. 73-97.

[12] Fleming, M. (2002). "Are Larger Treasury Issues More Liquid? Evidence from Bill Reopenings", Journal of Money, Credit and Banking 34: 707-735. 
[13] Garbade, K. and Ingber, J. (2005). "The Treasury Auction Process: Objectives, Structure, and Recent Adaptations", Federal Reserve Bank of New York, Current Issues in Economics and Finance series, Volume 11, Number 2.

[14] Guidolin, M. and Thornton, D. (2008), "Predictions of Short-term Rates and the Expectations Hypothesis of the Term Structure of Interest Rates", ECB Working Paper Series, No. 977, December.

[15] Jordà, Òscar and Salyer, K. D. (2003). "The Response of Term Rates to Monetary Policy Uncertainty", Review of Economic Dynamics, Vol. 6, pg. 941-962.

[16] Nyborg, K., Rydqvist, K. and Sundaresan. S. (2002). "Bidder Behavior in Multiunit Auctions: Evidence from Swedish Treasury Auctions", Journal of Political Economy 110: 394-424.

[17] Sarno, L. and Thornton, D. (2002), "The Dynamic Relationship Between the Federal Funds Rate and the Treasury Bill Rate: An Empirical Investigation", CEPR Discussion Paper, No. 3225, February.

[18] Smith, V. (1966). "Bidding Theory and the Treasury Bill Auction: Does Price Discrimination Increase Bill Prices?", The Review of Economics and Statistics 48: 141-146.

[19] Wingender, A. (2011). "Monetary Policy Shocks and Risk Premia in the Interbank Market", The B.E. Journal of Macroeconomics, Vol. 11 (1). 